ABDIRA Volume 2 Nomor 1 Tahun 2022 Halaman 221-232

JURNAL PENGABDIAN MASYARAKAT

Research \& Learning in Faculty of Education

\title{
Pelatihan Peningkatan Pemahaman Penggunaan Facebook dan Instagram pada Kelompok Petani Vanili dalam Penyebaran Informasi Pertanian
}

\author{
Gede Surya Mahendra1, I Putu Yoga Indrawan², Putu Gede Surya Cipta \\ Nugraha ${ }^{3}$ \\ Program Studi Teknik Informatika, STMIK STIKOM Indonesia \\ e-mail: gede.mahendra@stiki-indonesia.ac.id, yoga.indrawan@stiki-indonesia.ac.id, \\ surya.cipta@stiki-indonesia.ac.id
}

\begin{abstract}
Abstrak
Vanilla (Vanilla planifolia) memiliki harga yang mahal karena proses bercocok tanam dan panen rumit, yang juga dihadapi oleh mitra PKM. Kelompok tani vanili Bali mulai bangkit dari keterpurukan yang hampir lebih dari 10 tahun produksi vanili di Bali diserang hama pembusukan batang. Tujuan dari kegiatan PKM ini adalah memberikan pelatihan untuk Mitra PKM terhadap pemanfaatan media sosial dalam penyebarluasan informasi tentang tanaman vanili. Tahapan kegiatan PKM meliputi tahap identifikasi, persiapan, pelaksanaan, monitoring dan evaluasi serta pelaporan dan publikasi. Kegiatan PKM dilaksanakan pada tanggal 27 Juni 2021 dan 5 Juli 2021 yang berfokus pada pelatihan penggunaan facebook dan instagram. Kegiatan PKM dihadiri 6 orang petani vanili. Berdasarkan pretest dan posttest yang dilakukan terjadi peningkatan pengetahuan dari nilai pretest yang sebelumnya berada pada $42,74 \%$, pada posttest meningkat menjadi 75,24\%. Kegiatan PKM telah berhasil dilaksanakan dan tercapai pada kondisi baik.
\end{abstract}

Kata Kunci: Media Sosial, Vanili, Produk, Instagram, Facebook

\begin{abstract}
Vanilla (Vanilla planifolia) has a high price due to the complicated cultivation and harvesting process, which is also faced by PKM partners. The Balinese vanilla farmer group has started to recover from the slump that almost 10 years of vanilla production in Bali was attacked by stem rot pests. The purpose of this PKM activity is to provide training to PKM Partners on the use of social media in disseminating information about the vanilla plant. The stages of PKM activities include the stages of identification, preparation, implementation, monitoring and evaluation as well as reporting and publication. PKM activities will be held on 27 June 2021 and 5 July 2021 with a focus on training on the use of Facebook and Instagram. This PKM activity was attended by 6 vanilla farmers. Based on the pretest and posttest, there was an increase in knowledge from the previous pretest value of $42.74 \%$, in the posttest it increased to $75.24 \%$. PKM activities have been successfully implemented and achieved in good conditions.
\end{abstract}

Keyword: Social Media, Vanilla, Product, Instagram, Facebook

\section{PENDAHULUAN}

Vanilla (Vanilla planifolia) merupakan tanaman penghasil bubuk vanili yang sering dijadikan sebagai bumbu makan termahal kedua di dunia, sehingga 
nama lainnya adalah Green Gold (Kartikawati \& Rosman, 2018). Harganya mahal karena proses bercocok tanam dan panen lebih rumit dibanding tanaman lain. Amadeus Vanilla Beans, sebuah perusahaan penjualan vanilla di Amerika Serikat, menjual vanilla dari berbagai negara / daerah dengan harga di Indonesia dipatok \$ 38,99 per pon. Menurut standar permintaan pasar luar negeri, jumlah ini setara dengan Rp363.607 per pon atau Rp 797.735 per kilogram (kg) vanili kualitas terbaik.

Berbagai permasalahan yang dihadapi dalam pengembangan vanili Bali perlu ditangani secara lebih mendalam, komprehensif dan berkelanjutan guna mengembalikan citra vanili Indonesia di dunia sekaligus meningkatkan daya saing. Pemanfaatan teknologi komunikasi dan informasi dapat dijadikan alternatif tepat untuk dimanfaatkan oleh para petani sebagai media untuk berkomunikasi dengan masyarakat luas (Destrian, Wahyudin, \& Mulyana, 2018). Tentunya, platform media sosial saat ini memiliki makna strategis yang sangat penting dan dapat menjembatani segala macam hal. Media sosial merupakan solusi alternatif untuk mempercepat proses penyebaran informasi (Prayoga, 2017). Media sosial juga menjadi cara baru bagi orang untuk berkomunikasi. Perubahan penggunaan media konvensional menjadi cara digital seperti ini dapat memudahkan petani dalam melakukan kegiatan promosi. Dengan menggunakan kapabilitas teknologi informasi yang baik, produsen atau penjual dapat meningkatkan pemasarannya (Damayanti \& Bulan, 2017). Media sosial menjadi salah satu sarana pemasaran yang efektif karena media sosial merupakan sarana komunikasi yang banyak digunakan masyarakat saat ini (Tuwohingide, Israel, Papuas, Silangen, \& Koloay, 2018).

Kasus yang dialami oleh Kelompok Tani (Poktan) Marga Utama yang berlokasi di Banjar Beng, Desa Marga, Kecamatan Marga Kabupaten Tabanan, memiliki permasalahan yang sama dengan petani vanili lainya. Poktan yang diketuai oleh Bapak I Gusti Putu Sucipta, mulai bangkit dari keterpurukan yang hampir lebih dari 10 tahun produksi vanili di Bali, khusunya di Tabanan cukup terpuruk akibat hama pembusukan batang. Poktan yang sementara ini beranggotakan 10 orang dan terus berkembang, masih memiliki permasalahan terhadap penguasaan penggunaan media sosial. Beberapa kegiatan pelatihan mengenai penguasaan media sosial seperti Instagram dan facebook juga pernah dilakukan sebelumnya dan menghasilkan dampak yang baik bagi Mitra (Nasih, Sultoni, \& Kholidah, 2020; Prameka \& Dharma, 2019; Utomo, Qurrata, Purnamasari, \& Seprillina, 2019). Pelatihan kepada kelompok petani juga telah beberapa kali dilakukan sebelumnya dan juga mendapatkan respon positif oleh Mitra (Pamungkas, Wicaksono, \& Yunita, 2019; Suteja et al., 2020; Wangiyana, Wanitaningsih, \& Anggadhania, 2020).

Berdasarkan permasalahan yang dihadapi oleh mitra, untuk melakukan penyebarluasan informasi dan promosi produk terkait pertanian vanili, maka pelatihan terkait pengelolaan media sosial dapat menjadi prioritas dalam menyelesaikan permasalahan yang diharapi poktan Marga Utama Desa Marga. 
Setiap anggota poktan diharapkan memiliki media sosial, dapat mengelola media sosial, membuat konten digital, hingga mampu memberikan respon dan komentar yang baik dan benar. Pada dasarnya, kegiatan PKM ini diharapkan menjadi solusi terhadap permasalahan yang dihadapi oleh mitra melalui pendekatan secara terpadu, agar dapat meningkatkan kualitas poktan secara digital.

\section{METODE}

Pelaksanaan PKM ini dibagi menjadi lima tahap kegiatan yang meliputi tahap identifikasi, tahap persiapan, tahap pelaksanaan, tahap monitoring dan evaluasi serta tahap pelaporan dan publikasi (Paramitha, Mahendra, \& Artana, 2020). Adapun prosedur kerja dari kegiatan PKM ini dapat dilihat pada gambar 1 berikut.

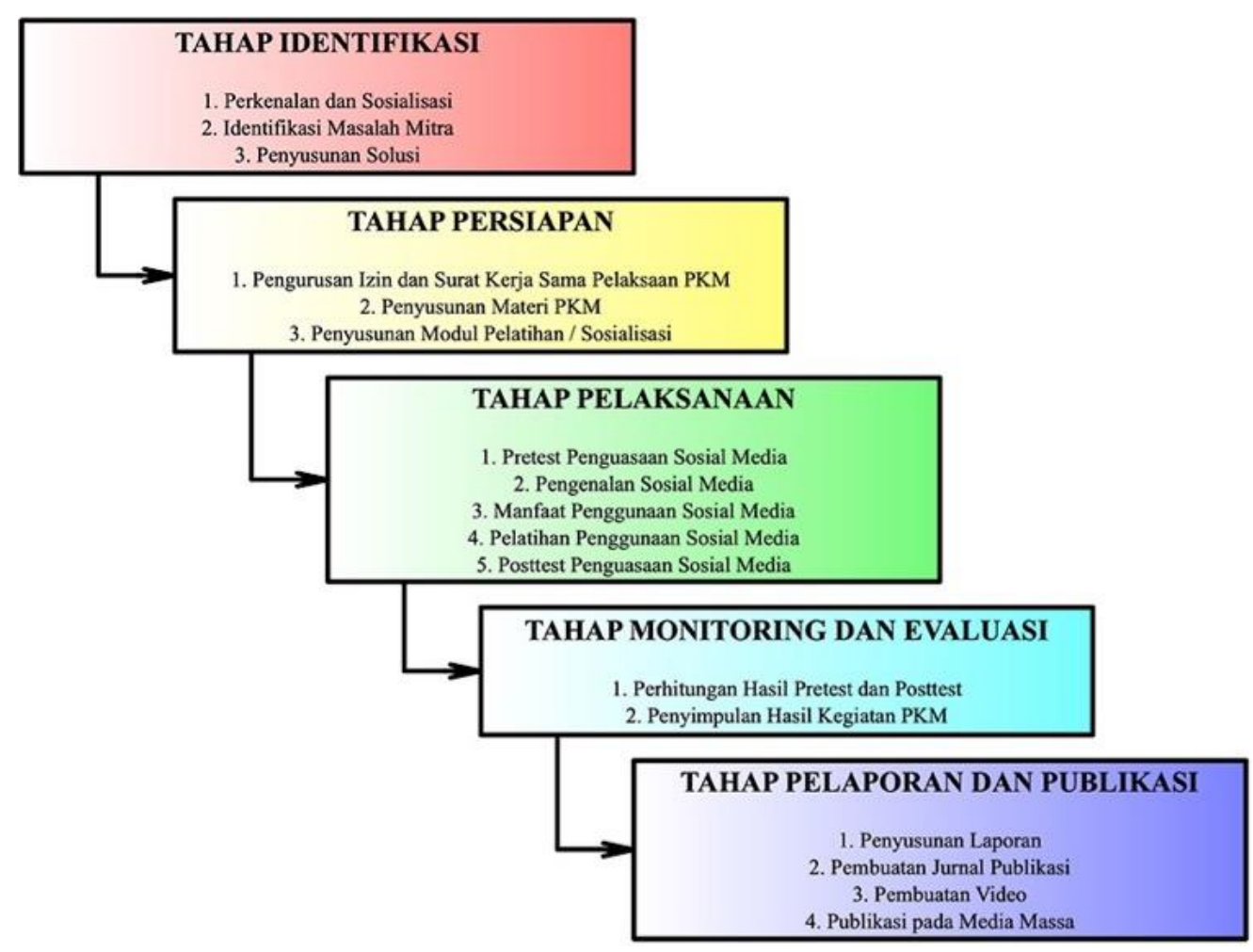

Gambar 1. Prosedur Kerja PKM

Kegiatan Pengabdian Kepada Masyarakat (PKM) ini bertujuan untuk melakukan pelatihan dan sosialisasi media sosial pada poktan Vanili di Desa Marga. Kegiatan PKM ini dilaksanakan pada tahun 2021 sejak bulan April hingga Desember dengan pelaksanaan sosialisasi pada fokus kegiatan pada tanggal 27 Juni 2021 dan 5 Juli 2021. Kegiatan PKM ini melibatkan 2 orang dosen Program Studi Teknik Informatika, STMIK STIKOM Indonesia. Kegiatan PKM ini dihadiri petani vanili sebanyak 6 orang. Kegiatan pelatihan pada PKM ini dilaksanakan berupa pelatihan dan sosialisasi penguasaan media sosial bagi 
penyebaran informasi kegiatan Poktan Vanili. Sosialisasi dilakukan secara lisan terkait dengan pemaparan materi mengenai pengenalan media sosial. Adapun proses kegiatan dimulai dari pembukaan oleh pihak mitra, memberikan paparan sosialisasi mengenai media sosial facebook dan instagram untuk pertanian, memberikan kesempatan untuk peserta melaksanakan tanya jawab tentang media sosial, dan penutupan kegiatan.

Pada tahap evaluasi, data respon peserta pelatihan dinilai menggunakan angket respon untuk mengukur indikator keberhasilan pelaksanaan PKM (Mahendra \& Nugraha, 2021). Angket respon dilakukan 2 kali sebagai pretest dan posttest. Indikator yang dinilai adalah kontribusi sosialisasi, kemampuan dan ketanggapan instruktur dan konten sosialisasi. Hasil respon peserta pelatihan dapat dinilai berdasarkan indikator capaian sebagai berikut.

Tabel 1. Kategori Capaian Keberhasilan Pelaksanaan PKM

\begin{tabular}{|c|c|}
\hline Interval (\%) & Kategori \\
\hline $81-100$ & Sangat Baik \\
\hline $61-80$ & Baik \\
\hline $41-60$ & Cukup Baik \\
\hline $21-40$ & Tidak Baik \\
\hline $0-20$ & Sangat Tidak Baik \\
\hline
\end{tabular}

\section{HASIL DAN PEMBAHASAN}

\section{a. Tahap Pelaksanaan}

Pelaksanaan PKM berfokus pada sosialisasi lapangan yang dilaksanakan selama 2 hari, yaitu pada tanggal 27 Juni 2021 dan 5 Juli 2021. Pelatihan dan sosialisasi dilaksanakan dengan mengindahkan protocol kesehatan dan Pelaksana PKM telah dilakukan Swab Test Antigen sebelum bertemu dengan Mitra PKM. Pada hari pertama, kegiatan dilakukan di Balai Banjar Beng, Desa Marga, Kecamatan Marga, Kabupaten Tabanan. Sosialisasi dilakukan secara lisan terkait dengan pemaparan materi mengenai pengenalan media sosial. Adapun proses kegiatan dimulai dari pembukaan oleh pihak mitra, memberikan paparan sosialisasi mengenai media sosial facebook dan instagram untuk pertanian, memberikan kesempatan untuk peserta melaksanakan tanya jawab tentang media sosial, dan penutupan kegiatan.

Pada hari kedua, kegiatan dilakukan di kebun milik anggota poktan. Hal ini dilakukan karena tanaman vanili di pekarangan mitra mengalami gagal tumbuh karena pembusukan batang dan proses kegiatan PKM dilimpahkan ke lokasi anggota lainnya yang kondisi tanaman vanilinya lebih baik dari milik ketua kelompok. Sosialisasi dilakukan secara lisan terkait dengan pemaparan materi mengenai pengenalan media sosial. Adapun proses kegiatan dimulai dari pembukaan oleh pihak mitra, pre-test, memberikan paparan sosialisasi mengenai media sosial facebook dan instagram untuk pertanian, memberikan kesempatan untuk peserta melaksanakan tanya jawab tentang media sosial, melakukan uji coba penggunaan media sosial, post-test dan penutupan kegiatan. Kegiatan 
dihadiri oleh 6 petani vanili. Berikut merupakan dokumentasi kegiatan dan hasil implementasi pelatihan media sosial yang dilaksanakan oleh Mitra.

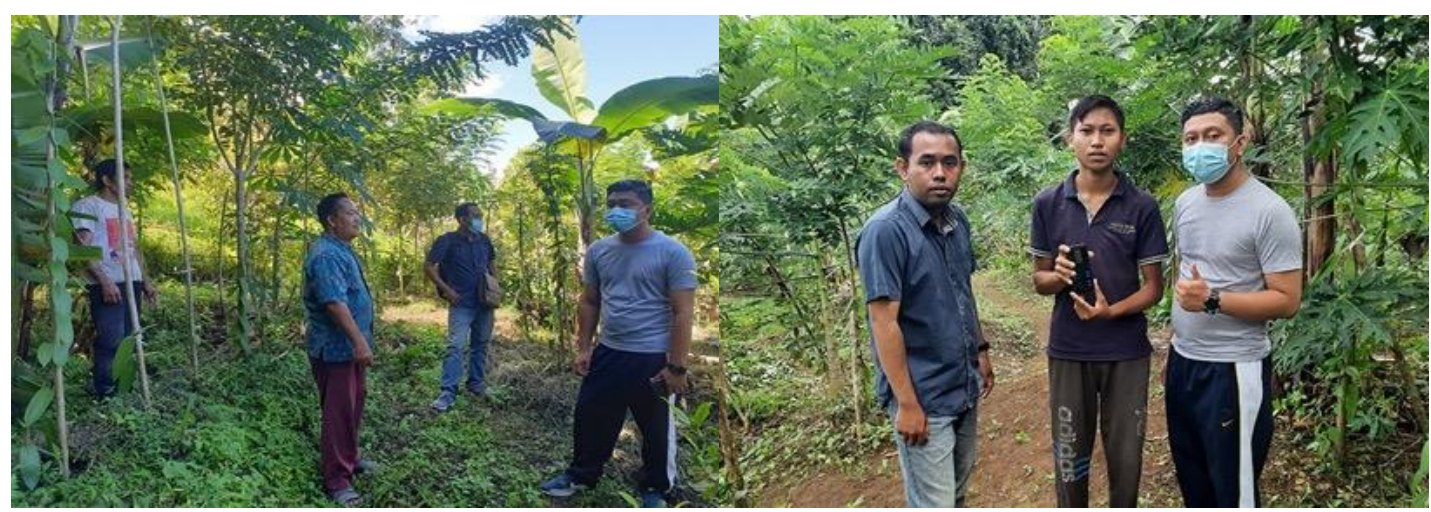

Gambar 2. Kunjungan pada Kebun Vanili Mitra dan Pelatihan Pengambilan Gambar untuk Media Sosial

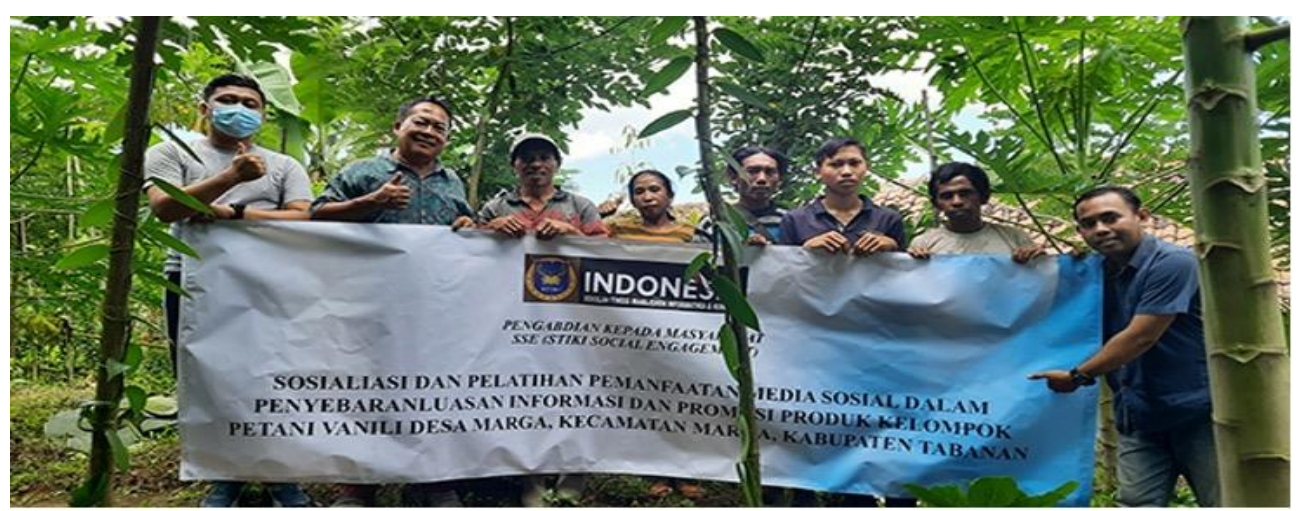

Gambar 3. Foto Dokumentasi dengan Petani Vanili
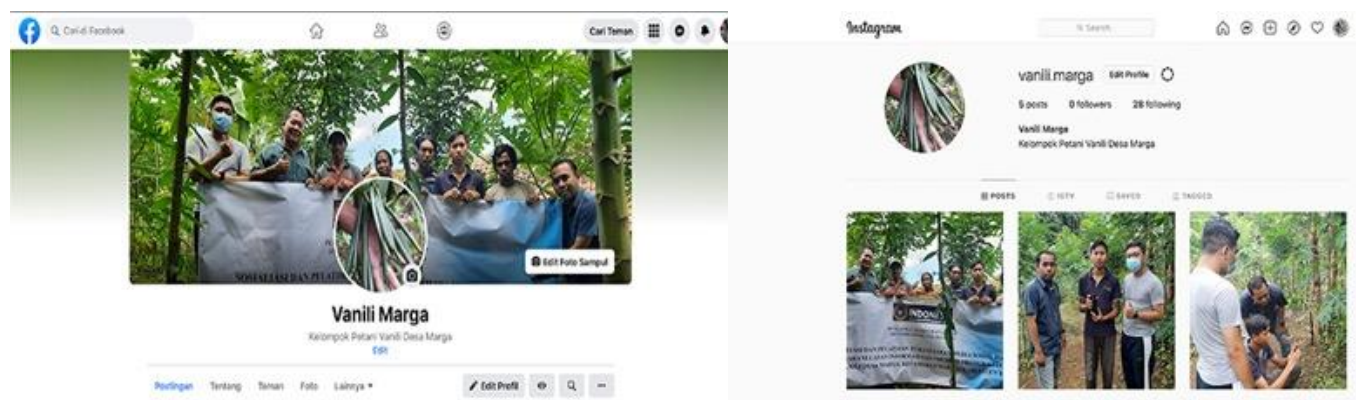

Gambar 4. Halaman Facebook dan Instagram yang Dikelola oleh Petani Vanili
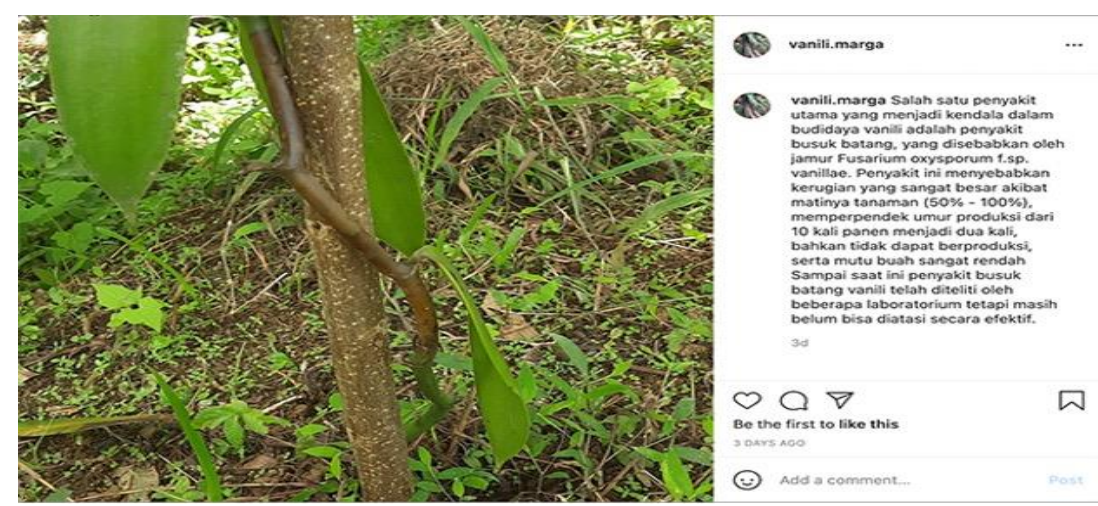

Gambar 5. Salah Satu Posting pada Instagram 


\section{b. Tahap Monitoring dan Evaluasi}

Pelaksana PKM menggunakan pretest, postest dan kuesioner untuk mengukur indikator keberhasilan seperti dijelaskan pada bagian sebelumnya tentang tahapan pelaksanaan kegiatan PKM. Tabel 2 menunjukkan indikator penilaian kegiatan pelaksanaan PKM. Nilai rata-rata posttest akan dijadikan acuan ketercapaian keberhasilan kegiatan PKM. Tabel 3 menunjukkan daftar pertanyaan bantuan dalam pretest dan posttest yang dilakukan untuk mendapatkan hasil penyerapan informasi dari kegiatan pelatihan dan sosialisasi PKM.

Tabel 2. Indikator Penilaian Pelaksanaan Kegiatan PKM

\begin{tabular}{|c|c|c|c|}
\hline No & Indikator & Item Penilaian & Rubrik Penilaian \\
\hline 1. & $\begin{array}{l}\text { Kontribusi } \\
\text { sosialisasi }\end{array}$ & $\begin{array}{ll}\text { - } & \text { Kemampuan awal (Pretest) } \\
\text { - } & \text { Kemampuan akhir (Posttest) } \\
\text { - } & \text { Keseriusan selama sosialisasi } \\
\text { - } & \text { Efektivitas instruktur } \\
\text { - } & \text { Materi yang jelas dan } \\
& \text { terstruktur }\end{array}$ & $\begin{array}{ll}\text { - } & \text { (Nilai Rata-Rata } \\
& \text { Pretest) } \\
\text { - } & \text { (Nilai Rata-Rata } \\
& \text { Posttest) } \\
\text { - } & 0-5 \\
\text { - } & 0-5 \\
\text { - } & 0-5\end{array}$ \\
\hline 2. & $\begin{array}{l}\text { Kemampuan } \\
\text { dan } \\
\text { ketanggapan } \\
\text { instruktur }\end{array}$ & $\begin{array}{ll}\text { - } & \text { Menarik minat } \\
\text { - } & \text { Efektivitas waktu belajar } \\
\text { - Suka membantu } \\
\text { - } \\
\text { - } \text { Asesmen dan penilaian cepat } \\
\text { Tujuan sosialisasi jelas }\end{array}$ & $\begin{array}{ll} & 0-5 \\
- & 0-5 \\
- & 0-5 \\
- & 0-5 \\
- & 0-5\end{array}$ \\
\hline 3. & $\begin{array}{l}\text { Konten } \\
\text { sosialisasi }\end{array}$ & $\begin{array}{ll}\text { - } & \text { Terstruktur dan terencana } \\
\text { - } & \text { Tugas cukup diberikan } \\
\text { - } & \text { Mengakomodasi partisipasi } \\
& \text { peserta }\end{array}$ & $\begin{array}{ll} & 0-5 \\
- & 0-5 \\
- & 0-5\end{array}$ \\
\hline
\end{tabular}

Tabel 3. Pretest dan Posttest Evaluasi Kegiatan PKM

\begin{tabular}{|c|c|c|c|}
\hline No & Pertanyaan & Opsi & $\begin{array}{c}\text { Rubrik } \\
\text { Penilaian }\end{array}$ \\
\hline 1 & $\begin{array}{l}\text { Apa saja media sosial } \\
\text { yang diketahui? }\end{array}$ & $\begin{array}{l}\text { - Tidak Tahu } \\
\text { - Facebook } \\
\text { - WhatsApp } \\
\text { - Instagram } \\
\text { - Twitter }\end{array}$ & $\begin{array}{l}-1 \\
\text { - } 1 \\
\text { - } 1 \\
\text { - } 1 \\
\text { - } 1\end{array}$ \\
\hline 2 & $\begin{array}{l}\text { Apa saja media sosial } \\
\text { yang digunakan? }\end{array}$ & $\begin{array}{l}\text { - } \text { Tidak Tahu } \\
\text { - Facebook } \\
\text { - WhatsApp } \\
\text { - Instagram } \\
\text { - Twitter }\end{array}$ & $\begin{array}{l}-1 \\
\text { - } 1 \\
\text { - } 1 \\
\text { - } 1 \\
\text { - } 1\end{array}$ \\
\hline 3 & $\begin{array}{l}\text { Seberapa baik } \\
\text { penguasaan media sosial }\end{array}$ & $\begin{array}{l}\text { - Tidak Bisa Menggunakan } \\
\text { - Sangat Tidak Baik }\end{array}$ & $\begin{array}{l}-0 \\
-1\end{array}$ \\
\hline
\end{tabular}




\begin{tabular}{|c|c|c|c|}
\hline No & Pertanyaan & Opsi & $\begin{array}{c}\text { Rubrik } \\
\text { Penilaian }\end{array}$ \\
\hline & $\begin{array}{l}\text { anda mengenai } \\
\text { Facebook? }\end{array}$ & $\begin{array}{l}\text { - } \text { Tidak Baik } \\
\text { - Cukup Baik } \\
\text { - Baik } \\
\text { - Sangat Baik }\end{array}$ & $\begin{array}{l}\text { - } 2 \\
\text { - } 3 \\
\text { - } 4 \\
\text { - } 5\end{array}$ \\
\hline 4 & $\begin{array}{l}\text { Seberapa baik } \\
\text { penguasaan media sosial } \\
\text { anda mengenai } \\
\text { WhatsApp? }\end{array}$ & $\begin{array}{l}\text { - Tidak Bisa Menggunakan } \\
\text { - Sangat Tidak Baik } \\
\text { - Tidak Baik } \\
\text { - Cukup Baik } \\
\text { - Baik } \\
\text { - Sangat Baik }\end{array}$ & $\begin{array}{l}-1 \\
-1 \\
-2 \\
\text { - } 3 \\
-4 \\
-5 \\
\end{array}$ \\
\hline 5 & $\begin{array}{l}\text { Seberapa baik } \\
\text { penguasaan media sosial } \\
\text { anda mengenai } \\
\text { Instagram? }\end{array}$ & $\begin{array}{l}\text { - Tidak Bisa Menggunakan } \\
\text { - Sangat Tidak Baik } \\
\text { - Tidak Baik } \\
\text { - Cukup Baik } \\
\text { - Baik } \\
\text { - Sangat Baik }\end{array}$ & $\begin{array}{l}-1 \\
-1 \\
-2 \\
-3 \\
-4 \\
-5 \\
\end{array}$ \\
\hline 6 & $\begin{array}{l}\text { Seberapa baik } \\
\text { penguasaan media sosial } \\
\text { anda mengenai Twitter? }\end{array}$ & $\begin{array}{l}\text { - Tidak Bisa Menggunakan } \\
\text { - Sangat Tidak Baik } \\
\text { - Tidak Baik } \\
\text { - Cukup Baik } \\
\text { - Baik } \\
\text { - Sangat Baik }\end{array}$ & $\begin{array}{ll} & 0 \\
- & 1 \\
- & 2 \\
- & 3 \\
- & 4 \\
- & 5\end{array}$ \\
\hline 7 & $\begin{array}{l}\text { Untuk memenangkan } \\
\text { persaingan bisnis pada } \\
\text { media sosial, media sosial } \\
\text { mana yang harus di } \\
\text { fokuskan untuk } \\
\text { meningkatkan kualitas } \\
\text { usaha anda? }\end{array}$ & $\begin{array}{l}\text { - Tidak perlu menggunakan } \\
\text { media sosial } \\
\text { - Facebook } \\
\text { - WhatsApp } \\
\text { - Instagram } \\
\text { - Twitter }\end{array}$ & $\begin{array}{ll}\bullet & 0 \\
\bullet & 0-5 \\
\bullet & 0-5 \\
- & 0-5 \\
- & 0-5\end{array}$ \\
\hline 8 & $\begin{array}{l}\text { Menurut anda, apa hal } \\
\text { penting yang harusnya } \\
\text { diperhatikan ketika } \\
\text { melakukan posting di } \\
\text { dalam media sosial? }\end{array}$ & $\begin{array}{l}\text { - Foto yang menarik } \\
\text { - Postingan (Text) yang menarik } \\
\text { - Waktu Ketika posting } \\
\text { - Susunan tata bahasa yang } \\
\text { digunakan }\end{array}$ & $\begin{array}{ll}- & 0-5 \\
- & 0-5 \\
\text { - } & 0-5 \\
\text { - } & 0-5\end{array}$ \\
\hline 9 & $\begin{array}{l}\text { Menurut anda, apa tujuan } \\
\text { dan manfaat dari } \\
\text { penggunaan media sosial } \\
\text { dalam melakukan usaha? }\end{array}$ & $\begin{array}{l}\text { - Memudahkan promosi } \\
\text { - Persaingan usaha yang sudah } \\
\text { online } \\
\text { - Hemat tempat } \\
\text { - Memudahkan proses penjualan } \\
\text { - Menguntungkan bagi usaha } \\
\text { - Jangkauan akses yang lebih luas } \\
\text { - Tidak perlu membayar sewa } \\
\text { toko }\end{array}$ & $\begin{array}{ll} & 0-5 \\
\text { - } & 0-5 \\
\text { - } & 0-5 \\
\text { - } & 0-5 \\
\text { - } & 0-5 \\
\text { - } & 0-5 \\
\text { - } & 0-5\end{array}$ \\
\hline
\end{tabular}


Berdasarkan hasil pretest, posttest dan kuisioner yang telah dilaksanakan terhadap 6 orang peserta pelatihan yang mengikuti kegiatan sosialisasi ini secara penuh, menunjukkan hasil yang positif dari masing-masing aspek yang menjadi indikator keberhasilan sosialisasi. Hasil pretest, posttest dan kuesioner terhadap penilaian pelaksanaan kegiatan PKM dilakukan secara manual dan menghasilkan luaran yang ditampilkan pada gambar-gambar grafik, sebagai berikut.

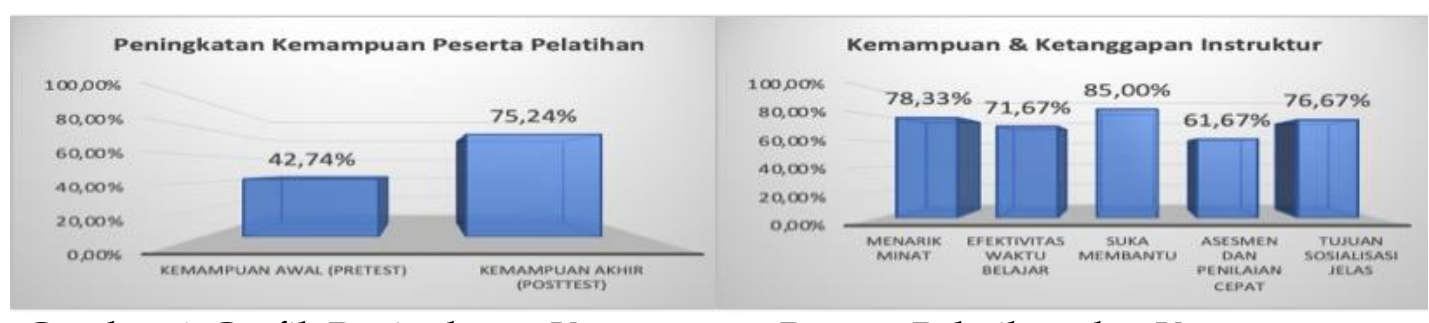

Gambar 6. Grafik Peningkatan Kemampuan Peserta Pelatihan dan Kemampuan dan Ketanggapan Instruktur

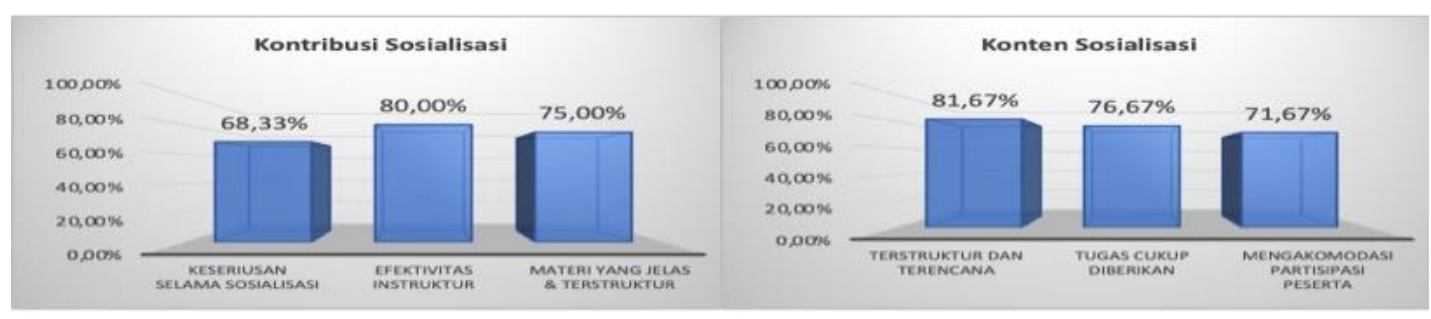

Gambar 7. Grafik Kontribusi Sosialisasi dan Konten Sosialisasi

Pada Gambar 7 dapat dilihat terdapat peningkatan yang cukup tinggi antara kondisi sebelum dan sesudah pelatihan yang ditunjukkan dari hasil ratarata pretest dan posttest. Rata-rata nilai pretest yang sebelumnya berada pada $42,74 \%$, pada posttest meningkat menjadi $75,24 \%$ sehingga termasuk pada kategori baik untuk ketercapaian keberhasilan program PKM. Untuk detail perkembangan kemampuan peserta sosialisasi akan dibahas lebih detail selanjutnya. Pada Gambar 7 juga menunjukkan grafik kemampuan dan ketanggapan instruktur yang memiliki indikator menarik minat, efektivitas waktu belajar, suka membantu, asesmen dan penilaian cepat serta tujuan sosialisasi jelas. Dari grafik tersebut dapat dilihat yang paling rendah adalah indikator asesmen dan penilaian cepat yang hanya mencapai $61,67 \%$, dimana hal ini dipengaruhi oleh pemberian test secara manual dan bergantian sehingga membutuhkan waktu yang cukup lama. Pada Gambar 8 menunjukkan grafik kontribusi sosialisasi yang memiliki indikator keseriusan selama sosialisasi, efektivitas instruktur, serta materi yang jelas dan terstruktur. Dari grafik tersebut dapat dilihat yang paling rendah adalah indikator keseriusan selama sosialisasi yang hanya mencapai $68,33 \%$, dimana hal ini menjadi perhatian bagi pelaksana PKM untuk dapat ditingkatkan lagi kedepannya. Pada Gambar 8 juga menunjukkan grafik konten sosialisasi yang memiliki indikator terstruktur dan terencana, tugas cukup diberikan, dan mengakomodasi partisipasi peserta. Dari grafik tersebut dapat dilihat yang paling rendah adalah indikator mengakomodasi partisipasi peserta yang hanya mencapai $71,67 \%$, dimana hal ini 
dipengaruhi oleh ketimpangan pengetahuan antar peserta sosialisasi sehingga peserta yang sama sekali tidak memiliki dasar pengetahuan terhadap media sosial merasa ditinggalkan, sehingga hal ini harus menjadi refleksi pelaksana PKM untuk membuat skema yang lebih baik dalam pemberian sosialisasi.

Lebih lanjut mengenai pretest dan posttest yang diberikan kepada peserta sosialisasi, juga masih menggunakan cara manual. Terdapat 4 segmen penilaian pada pretest dan posttest, yaitu indikator perkembangan kemampuan media sosial, perkembangan pemahaman fokus pengembangan media sosial, perkembangan pemahaman fokus pembuatan konten serta perkembangan pemahaman manfaat penggunaan media sosial bagi bisnis. Gambar-gambar grafik dari hasil pretest dan posttest yang dilakukan pada kegiatan PKM ditampilkan sebagai berikut.

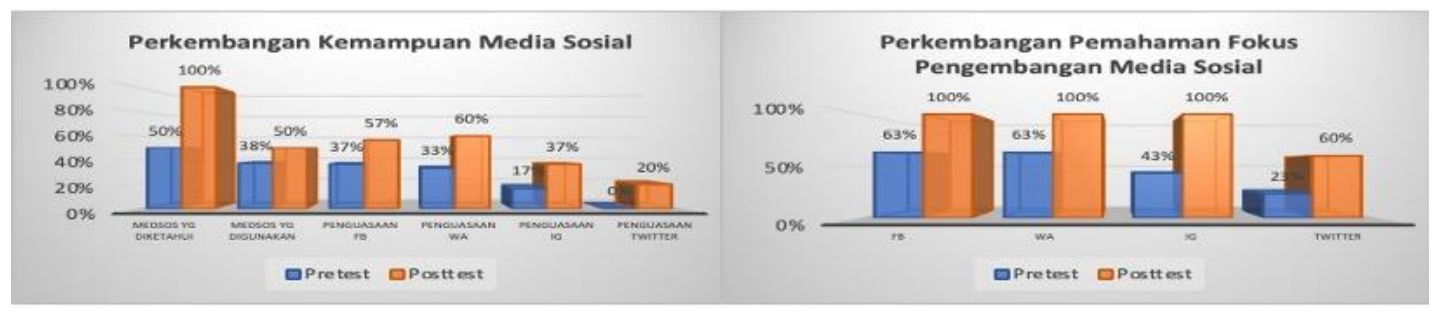

Gambar 8. Grafik Perbandingan Pretest dan Posttest pada Indikator

Perkembangan Kemampuan Media Sosial dan Perkembangan Pemahaman

Fokus Pengembangan Media Sosial

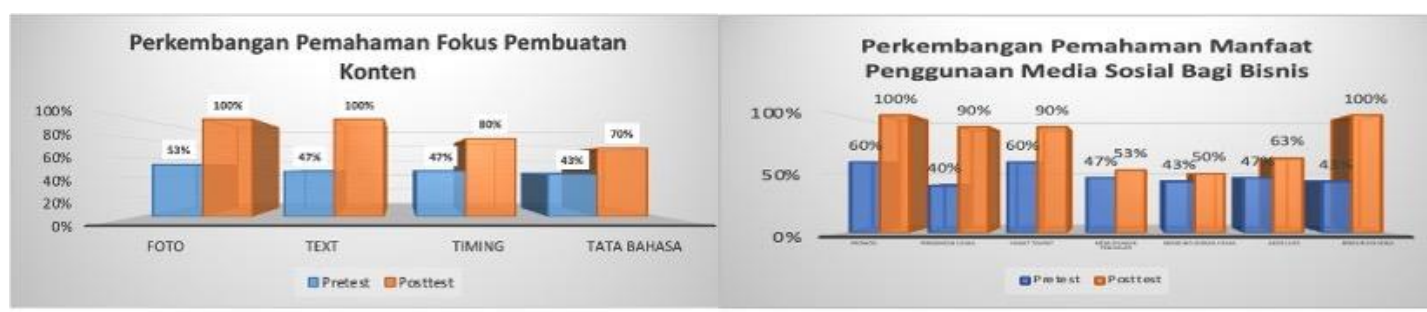

Gambar 9. Grafik Perbandingan Pretest dan Posttest pada Indikator

Perkembangan Pemahaman Fokus Pembuatan Konten dan Perkembangan

Pemahaman Manfaat Penggunaan Media Sosial terhadap Bisnis

Pada Gambar 9 menunjukkan grafik perbandingan pretest dan posttest pada indikator perkembangan kemampuan media sosial yang memiliki indikator media sosial yang diketahui, media sosial yang digunakan, penguasaan penggunaan Facebook, penguasaan penggunaan WhatsApp, penguasaan penggunaan Instagram serta penguasaan penggunaan Twitter. Dari grafik tersebut dapat dilihat pada pretest, kemampuan media sosial terendah terdapat pada media twitter yang hanya diketahui sedikit dari peserta namun sama sekali tidak pernah menggunakannya. Setelah dilakukan posttest pada seluruh peserta, mereka menjadi mengetahui seluruh media sosial yang ditawarkan, namun masih tidak tertarik mempelajari lebih lanjut mengenai twitter. WhatsApp dan Facebook menjadi faktor dominan dalam hal yang ingin dikuasai oleh peserta pelatihan. Pada Gambar 9 juga menunjukkan grafik perbandingan pretest dan posttest pada indikator perkembangan pemahaman fokus pengembangan media sosial yang memiliki indikator fokus pada Facebook, fokus pada WhatsApp, 
fokus pada Instagram serta fokus pada Twitter. Dari grafik tersebut dapat dilihat pada pretest dan posttest, peserta sosialisasi masih belum tertarik pada penguasaan penggunaan twitter. Setelah diadakan posttest, ternyata fokus mereka dominan pada Facebook, WhatsApp dan Instagram.

Pada Gambar 10 menunjukkan grafik perbandingan pretest dan posttest pada indikator perkembangan pemahaman fokus pembuatan konten yang memiliki indikator fokus pada foto, text, timing dan tata bahasa. Dari grafik tersebut dapat dilihat pada pretest tidak jauh berbeda antar indikator, namun fokus didominasi pada kualitas foto pada media sosial. Pada hasil posttest menunjukkan bahwa foto dan text menjadi fokus utama pada fokus pembuatan konten. Pada Gambar 10 juga menunjukkan grafik perbandingan pretest dan posttest pada indikator perkembangan pemahaman manfaat penggunaan media sosial terhadap bisnis yang memiliki manfaat penggunaan media sosial pada segmen promosi, persaingan usaha, hemat tempat, memudahkan penjualan, menguntungkan usaha, akses luas dan bebas biaya sewa. Dari grafik tersebut dapat dilihat pada pretest tidak jauh berbeda antar indikator, namun manfaat yang paling rendah dirasakan pada segmen keuntungan usaha dan bebas biaya sewa. Pada hasil posttest menunjukkan bahwa manfaat media sosial paling besar dirasakan pada promosi usaha dan bebas biaya sewa.

Selain kondisi pandemi COVID-19, terdapat beberapa kendala yang pelaksana sosialisasi hadapi sejak tahap penjajagan awal hingga berakhirnya kegiatan PKM. Terdapat kondisi hama jamur yang menyebabkan terjadinya busuk batang pada tanaman vanili sehingga membuat sebagian besar tanaman mati yang mengakibatkan tanaman gagal tumbuh dan masa panen harus mundur hingga 1-2 tahun kedepan. Hal ini hanya dapat ditanggulangi dari petani vanili dengan cara mengontrol kondisi tanaman vanili pada pengaturan kondisi kelembaban, kontrol gulma dan hama, dan faktor-faktor pertanian lainnya. Terdapat beberapa peserta pelatihan yang tidak memiliki gadget dan tidak pernah sama sekali menggunakan media sosial, sehingga terdapat pengetahuan yang timpang antar peserta sosialisasi. Hal ini sementara dapat ditangani dengan memberikan pelatihan lebih intensif pada peserta pelatihan yang mengerti dengan penggunaan smartphone dan media sosial. Namun kondisi ini tidak boleh dibiarkan dan harus mendapatkan penanganan khusus lebih lanjut seperti pengenalan penggunaan smartphone. Kondisi sinyal pada lokasi kegiatan tidak terlalu baik, karena berada pada dataran tinggi, sehingga posting pada media sosial mengalami waktu tunggu yang cukup lama.

\section{c. Tahap Pelaporan dan Publikasi}

Setelah kegiatan inti selesai dilaksanakan, pelaksana PKM melanjutkan kegiatan PKM dengan penyusunan laporan akhir. Pelaksana PKM juga berkewajiban untuk melakukan pembuatan jurnal publikasi kegiatan PKM. Terdapat juga kegiatan untuk pembuatan video pemaparan kegiatan serta publikasi pada media massa. 


\section{SIMPULAN}

Berdasarkan kegiatan yang telah dilaksanakan pada kegiatan Sosialisasi dan Pelatihan Pemanfaatan Media Sosial dalam Penyebarluasan Informasi dan Promosi Produk Kelompok Petani Vanili, Desa Marga, Kecamatan Marga, Kabupaten Tabanan dengan mitra Kelompok Tani Marga Utama, Desa Marga dapat disimpulkan bahwa terjadi peningkatan kemampuan Mitra dalam penggunaan media sosial dengan kategori baik. Berdasarkan pretest dan posttest yang dilakukan terjadi peningkatan pengetahuan dari nilai pretest yang sebelumnya berada pada $42,74 \%$, pada posttest meningkat menjadi $75,24 \%$.

\section{DAFTAR PUSTAKA}

Damayanti, \& Bulan, W. R. (2017). PKM Pemanfaatan Media Sosial Instagram Kelompok UKM Kuliner Depok. Prosiding Seminar Hasil Pengabdian Kepada Masyarakat, 4(2), 1-15.

Destrian, O., Wahyudin, U., \& Mulyana, S. (2018). Perilaku Pencarian Informasi Pertanian melalui Media Online pada Kelompok Petani Jahe. Jurnal Kajian Komunikasi, 6(1), 121. https:/ / doi.org/10.24198/jkk.v6i1.12391

Kartikawati, A., \& Rosman, R. (2018). Sirkuler Informasi Teknologi Tanaman Rempah dan Obat-Budidaya Vanili. Bogor: Balai Penelitian Tanaman Rempah dan Obat.

Mahendra, G. S., \& Nugraha, P. G. S. C. (2021). Pelatihan Perangkat Desa dalam Penggunaan Sistem Pengaduan Online Berbasis Web (EC-Resolver) Untuk Menuju Desa Digital. Jurnal Masyarakat Mandiri, 5(3), 918-929. https://doi.org/10.31764/jmm.v5i3.4481

Nasih, A. M., Sultoni, A., \& Kholidah, L. N. (2020). Kajian Konten Media Sosial untuk Penguatan Literasi Dakwah Islam Moderat Guru dan Santri di Pesantren. Jurnal Karinov, 3(3), 174-180.

Pamungkas, T. S., Wicaksono, G., \& Yunita, R. (2019). Pelatihan dan Pendampingan Kelompok Petani Kopi Desa Solor Kabupaten Bondowoso. Jurnal Inovasi Sosial \& Pengabdian Kepada Masyarakat (Syukur), 2(2), 101-106. https://doi.org/10.22236/syukur_vol2/is2pp101-106

Paramitha, A. A. I. I., Mahendra, G. S., \& Artana, I. M. (2020). Sosialisasi dan Pelatihan Internet Marketing Bagi UMKM Sokasi di Desa Tigawasa. Jurnal Karya Abdi, 4(2), 276-283.

Prameka, A. S., \& Dharma, B. A. (2019). Perancangan dan Pengembangan Pusat bisnis Berbasis Online Produk Unggulan Desa Sejahtera Mandiri (DSM) Kucur, Dau-Kabupaten Malang. Jurnal Karinov, 2(1), 33-38.

Prayoga, K. (2017). Pemanfaatan Sosial Media Dalam Penyuluhan Pertanian Dan Perikanan Di Indonesia. Agriekonomika, 6(1). https://doi.org/10.21107/agriekonomika.v6i1.2680

Suteja, R. S. A., Isnaini, S., Dayanti, L. D., Suryandaru, Y. S., Surya, Y. W. I., Saptyasari, A., ... Wibawa, I. S. (2020). Elatihan Komunikasi Pemasaran dalam Rangka Pemberdayaan Ekonomo Masyarakat Petani Mente Desa Soket Laok, Kabupaten Bangkalan, Madura. Jurnal Layanan Masyarakat (Journal of Public Services), 4(2), 312-317. 
https://doi.org/10.20473/jlm.v4i2.2020.312-317

Tuwohingide, D., Israel, E. H., Papuas, A., Silangen, M., \& Koloay, C. (2018). PKM Pemanfaatan Media Sosial Untuk Promosi dan Pemasaran Produk Usaha Kecil Menengah di Kampung Bowongkulu. Jurnal Ilmiah Tatengkorang, 2(1), 48-52.

Utomo, S. H., Qurrata, V. A., Purnamasari, V., \& Seprillina, L. (2019). Peningkatan Omset Penjualan Melalui Media Sosial Pada Usaha Kecil Menengah Alas Kaki Berbahan Kulit. Jurnal Karinov, 2(1), 57-61.

Wangiyana, I. G. A. S., Wanitaningsih, S. K., \& Anggadhania, L. (2020). Pelatihan Teknologi Bio-induksi untuk Petani Gaharu di Desa Pejaring, Kabupaten Lombok Timur. Agrokreatif: Jurnal Ilmiah Pengabdian kepada Masyarakat, 6(1), 36-44. https:/ / doi.org/10.29244/agrokreatif.6.1.36-44 